\title{
Parental Financial Support and Students Motivation in Learning
}

\author{
Jerald C. Moneva \\ Department of Education-Mandaue City Division \\ Mandaue City, Cebu, Philippines \\ Tel: +639-08-927-3038Ｅ-mail: freezingfire1979@gmail.com \\ Raisha Fe L. Pestano \\ Jagobiao National High School \\ Mandaue City, Cebu, Philippines \\ Tel: +639-56-963-6457Ｅ-mail: raisha.pestano19@gmail.com
}

\author{
Ria M. Vertulfo \\ Department of Education Division of Cebu Province \\ Mandaue City, Cebu, Philippines \\ E-mail: ria.vertulfo@deped.gov.ph
}

Received: February 4, 2020

Accepted: March 11, 2020

Published: April 20, 2020

doi:10.5296/iss.v8i1.16908

URL: http://dx.doi.org/10.5296/iss.v8i1.16908

\begin{abstract}
The capacity of the parents to provide financially the needs of the students in their studies is referred to as parental financial support. While motivation is the personal drive or will of a person to do a task without the influence of other people. A checklist survey questionnaire was used to assess the parental financial support and motivation of students in learning. The data gathered were treated through weighted mean and chi-square. In which, it revealed that students were more motivated when they are financially supported by their parents when it comes to educational purposes. Therefore, it shows that there is a significant association between parental financial support and students' motivation in learning.
\end{abstract}

Keywords: Learning, Motivation, Parental Financial Support 


\section{Introduction}

\subsection{Rationale}

Parental financial support of young adults is significantly tied to the financial resources and other characteristics of the family of origin. Meanwhile, motivation is the act or process of giving someone a reason for doing something: the act or process of motivating someone (Merriam Webster Dictionary, 1828).

The researcher believes that parental financial support have a great influence on students' motivation in learning. The students need to study hard in order for them to be prepared in the future and not to be dependent with their parents. Nevertheless, students need the support of their parents because they cannot still provide their own. Most of the students strive hard by themselves due to the lack of financial support from their parents. It leads to the decrease of motivation towards their studies. Students' motivation in learning is very important because it will help them learn effectively and to become a functional individual. If students are motivated, they will retain information easily and not disrupt on the things they do.

Learners get motivated when their parents who appreciate and proud on their achievements and performance (Ghazi, Ali, Shahzad, Khan, \& Hukamdad, 2010). Motivation has a great impact on students' success (Ozen, 2017). Students who were goal-oriented, give importance their learning and trust their capabilities in handling challenges in academic demands will have a prosperous achievements (Radovan, 2011).

The researcher tends to determine the association between the two variables parental financial support and students' motivation in learning among the students in Jagobiao National High School.

\subsection{Theoretical Background}

A psychologist believed that all people have needed to satisfy that they will work satisfying those need. A need is what a person requires. He assumed these need could be arranged according to their importance in a step known as Maslow's hierarchy of need. This study is supported by theory of Hierarchy of needs theory of Motivation proposed by Abraham Maslow (1908-1970).

Maslow's hierarchy of needs has five levels presented by a pyramid. Physiological needs include the most basic needs that are vital to survival, such as the need for water, air, food, and shelter. Second is security needs include the desires for safety and security. Third is social needs include needs of belonging, love and affection. Fourth is esteem needs, when the first three needs have been satisfied, esteem needs become increasingly important. Lastly self-actualizing needs assume the highest level of Maslow's hierarchy of needs.

Human actions are motivated in order to achieve certain needs. People have a need to accomplish things and have their efforts recognized. In social studies the theory of Abraham Maslow on human motivation is considered a seminal work. Frequently, Maslow's theory of human motivation is cited as a general description of the priorities of what humans need and want. In Maslow's thinking the individual is seen as the most important actor and his/her 
individual energy supersedes other motivations of action (Maslow, 1948).

In related to the study, students motivation in learning because students need to be motivated in order for them to have good performance in school it will help them learn effectively and to become a functional individual.

Esteem Needs which Maslow classified into two categories, esteem for oneself (dignity, achievement, mastery, independence) and desire for reputation or respect from others (status, prestige). It is the most essential factor in the students learning atmosphere. Maslow indicated that the need for respect or reputation is most important for children and adults and precedes real self-esteem or dignity.

When a person lacks that sense of self-worth, it can eventually lead to feelings of depression where the individual feels like they are short of the expected potential or expected set of abilities. On one hand, too much love for one's self gives a certain sense of power and inability to accept mistakes. Either way of social relationships are affected when they find themselves of both extreme sides. It is important to know more about self-esteem because it motivate and help them realize things like who they really are as a unique individual. How they face challenges in life that gives meaning to their actions. It also helps them define life goals and gives more specific definition on what direction they are working towards in their future.

\subsection{Statement of Purpose}

The study intends to assess the correlation between parental financial support and students' motivation in Learning.

\subsection{Review of Related Literature}

Parents' contribution to their children's' education has a consistent and positive effect on academic achievement and on the self-concept (Chohan \& Khan, 2010). Young adults' housing outcomes have changed considerably over time and are persistently stratified by parental class and tenure in ways that vary by gender (Coulter, 2018). Consequently, parents must give support and motivate their children to join activities related to academic (Dojillo, Balandra, Lebuna, \& Lopez, 2017). Both income and assets have consistent long-term associations with children's college entry (Huang, Guo, Kim, \& Sherraden, 2009). Parents were inconsistent in providing home environments that support their children's development of internalized form of academic motivation (Garn, Matthews, \& Jolly, 2011). The effects of parent's education on the selectivity of the college attended are also dependent on aligned ambition and aligned action between parents and adolescents (Kim \& Schneider, 2017).

Families differ widely in the support they provide to all adult offspring, both with regard to the overall level as well as the extent to which support is evenly distributed to their offspring (Kim, Fingerman, Birditt, \& Zarit, 2015). Parents' involvement in children school activities matter most than to parent's financial status in uplifting the children academic performance in school (Machebe, Ezegbe, \& Onuoha, 2017). Parent should regularly involved in the academic irrespective of their financial status (Masabo, Muchopa, \& Kuoth, 2017). Parental 
participation plays a pivotal role in motivating children to improve their academic grades (Mahuro \& Hungi, 2016).

Financial knowledge and parental verbal instruction appear to have complex relationships to credit card debt (Norvilitis \& Maclean, 2010). Students showed higher academic performance whose parents were more supportive and involve in academic activities as compared to those whose parents were less supportive (Shahzad, n. d.) Majority of the parents required their children to remain at home after they graduated as they cannot support themselves financially (West, Lewis, Roberts, \& Noden, 2016). Parents' school attainment is an essential predictor particular at the high end of the socio-economic allocation (Wightman, Patrick, Schoeni, \& Schulenberg, 2013).

Motivation is very important to have a different idea and describing its core characters that require particular care (Dornyie, 2009). Students who were approach oriented have a high motivation by their desire to perform better and to show their outmost ability (Ferla, Valeke, \& Schuyten, 2010). Positive reinforcement sources like gifts and prizes should be used to improve children's performance (Ali, Shahzad, Khan, \& Hukamdad, 2010). It was seen that within the responses, the need for achievement and the need for affiliation were more common motives for joining the voluntary, residential leadership learning community (Moore, Grabsch, \& Rotter, 2010). Learners who engaged in reflexive observations are more equip because they are motivated enough to transfer their learning than those students engaged in the field of experiment (Olivos,Canas- Carreton, Martin- Martinez, \& Gomez-Lazaro,2016). Motivation showed to have a positive low level positive effect on student's academic success (Ozen, 2017). On one hand, Intrinsic goal orientation, task value and self-efficacy and effort regulation strategies led to higher academic success (Radovan, 2011). Graduate students learning online reported higher levels of critical thinking than undergraduates (Artino \& Stephens, 2009).

Significantly, students must get facility to be motivated to learn and be better (Riswanto \& Aryani, 2017). Motivation leads students' motives into essential academic activities (Saeed \& Zynyier, 2012). There is a relation between student's self-oriented learning readiness, academic self-efficacy and academic motivation of the students (Saeid \& Eslaminejad, 2017). There is no significant differences were found between male and female students, with regards to their motivation (Saleh, 2014). Motivation was seen as the actions and influences of the students (Seifert, 2004). Most students had a relatively high level of motivation but the level of learning was not assessed to be as high (Vibulphol, 2016). Constructing a game might be a better way to enhance student motivation and deep learning than playing an existing game (Vos, Meijden \& Denessen, 2011).

\section{Research Method}

\subsection{Design}

The study was designed to assess the descriptive correlation between Parental financial Support and Students Motivation in Learning. 


\subsection{Environment}

This study was conducted in Jagobiao National High School located at North road Jagobiao Mandaue City. This school was known before as Mabini National High School and was built in 1984. They added Senior High School as part of K12 Curriculum in 2015. The senior high school building consist of 2 buildings and it can be seen in the lower part of Junior high school building. The first building has 6 rooms that is occupied by Grade 11 students which are Humanities and Social sciences (HUMSS) Technical Vocational and Livelihood (TVL) Accountancy and Business Management (ABM) and General Academic Strand (GAS) that includes the faculty and computer laboratory. While the second building has 8 rooms and occupied by the Grade 12 and 11 students which are ABM, GAS, HUMSS and grade 11 STEM.

\subsection{Respondents}

The chosen respondents are all senior high school students particularly in Grade 11 and Grade 12 students. There were 16 males and 19 females for a total of 35 respondents in the class of STEM 11. There were 19 males and 24 females for a total of 43 respondents in the class of HUMSS 11. There were 6 males and 21 females for a total of 27 respondents in the class of ABM 11. There were 14 males and 26 females for a total of 40 respondents in the class of GAS 11. There were 8 males and 0 female for a total of 8 respondents in the class of TVL 11. There were 8 males and 21 females for a total of 29 respondents in the class of ABM 12. There were 8 males and 15 females for a total of 23 respondents in the class of GAS 12 . There were 14 males and 31 females for a total of 45 respondents in the class of HUMSS 12 . All in all, there were 250 respondents from Grade 11 and Grade 12 students.

\subsection{Data Gathering Procedure}

The researcher asked permission and approval of the school head to conduct the study including all senior high school students in senior high school department of Jagobiao National High School. The researcher used survey questions as a guide in conducting the study. The researcher also personally allocates the research instrument to the respondents.

The respondents were given 5 minutes to answer the questions on a 1 whole sheet of bond paper given by the researcher. After 5 minutes the researcher collected the data and went from one section to another. The data collected was tallied and tabulated and this would be the basis of analysis and interpretation.

\subsection{Instrument}

The researcher used the information sheet which is checklist as the tool instruments which contains difference that would lead the result of this study. The researcher provided two checklists for each variable, every checklist contain 10 items. The first checklist is all about parental financial support while the second checklist is all about student's motivation in learning. The respondents rate the checklist provided 1 for never, 2 for sometimes and 3 for always. Data were collected with the aid of checklist to evaluate the correlation between students level of Parental financial Support and Motivation in Learning among Senior High 
School students.

\section{Data Analysis and Discussion}

Table 1. Parental financial support

\begin{tabular}{lcl}
\hline INDICATORS & $\begin{array}{c}\text { Weighted } \\
\text { Mean }\end{array}$ & Interpretation \\
\hline 1. My parents support me financially in my study & 2.74 & Always \\
2. My parents can give me enough money for my projects and activities & & \\
in school & 2.47 & Always \\
3. I am satisfied with my daily allowance & 2.45 & Always \\
4. I don't feel worried about my payments in school & 2.19 & Sometimes \\
5. My parents give me extra money for my personal needs & 2.12 & Sometimes \\
6. My parents give me money immediately when I asked for it & 2.04 & Sometimes \\
7. I am able to save money from my daily allowance & 2.25 & Sometimes \\
8. I do not need to borrow money from my classmates & 2.09 & Sometimes \\
9. I can buy a complete requirements in school & 2.27 & Sometimes \\
10. I can spend my extra allowance to my wants and needs & 2.30 & Sometimes \\
\hline Overall Weighted Mean & 2.29 & Sometimes \\
\hline
\end{tabular}

LEGEND: 1.0-1.66-(NEVER); 1.67-2.33 (SOMETIMES); 2.34-3.00 (ALWAYS).

The table above revealed that the 10 indicators had three highest and lowest weighted mean and it was rated as Always and Sometimes. The first three highest weighted mean was 2.45, the second one was 2.47 and the last highest weighted mean was 2.74. The three lowest mean was interpreted as sometimes was 2.04, the second one was 2.09, and the last lowest weighted mean was 2.04. While the overall weighted mean was 2.29. And it was interpreted as sometimes. Similarly, the study of Chohan and Khan (2010) supports the result above that the parents' financial support affects the students' academic success and self-concept. Consequently, the study of Dojillo, Balandra, Lebuna and Lopez (2017) revealed that the parents of BSHRM are highly supportive in extending their financial and moral support. According to the study of Masabo, Muchopa and Kuoth (2017) that teachers disagrees that parental involvement did not affect the academic success of the students. 
Table 2. Students motivation in learning

\begin{tabular}{lll}
\hline & Weighted & \\
INDICATORS & Mean & Interpretation \\
\hline 1.I seek opportunities to excel & 2.33 & Sometimes \\
2. I worry about deadlines and getting things done, which causes stress & & \\
and anxiety & 2.37 & Always \\
3. I believe that if I work hard and apply my abilities and talents, I will & & \\
be successful & 2.72 & Always \\
4. I think positive about setting goals and making sure my needs are met & 2.49 & Always \\
5. I set goals and objectives in annual basis to achieve what I aspire for & & \\
life & 2.45 & Always \\
6. I reward myself when accomplishing significant goals & 2.20 & Sometimes \\
7. I set challenging goals for myself & 2.35 & Always \\
8. I am motivated to learn & 2.58 & Always \\
9. I know my strength & 2.56 & Always \\
10. I try to keep myself focused on my goals & 2.51 & Always \\
\hline Overall Weighted Mean & 2.46 & Always \\
\hline
\end{tabular}

Part 2 Students Motivation in Learning

LEGEND: 1.0-1.66 - (NEVER); 1.67-2.33 (SOMETIMES); 2.34-3.00 (ALWAYS)

The table above revealed that the overall weighted mean is 2.46 and was interpreted as always. The 10 indicators had three highest and two lowest weighted mean that was rated as always and sometimes. The first three highest weighted mean was 2.72 which stated that students will be successful when they work hard and applies their abilities and talents. Ferla, Valke and Schuytan (2010) stated that students are motivated mainly by their strong desire to outperform others. The second highest weighted mean has 2.58 which indicated that students are motivated to learn. This is in line with Ghazi's (2010) findings which revealed that students were motivated when their performance are appreciated and praised by their parents. The last one was 2.56 which indicated that students know their strength. The first lowest weighted mean was 2.20 which mean that students sometimes reward themselves when they accomplish their goals. The second one is 2.33 which revealed that students sometimes find opportunities to learn. The third lowest weighted mean was 2.35 which stated that students always sets challenging goals for themselves. Radovan (2011) found out that students that have goal-setting, task value, self-efficacy, and effort regulation were the main strategies that lead to better academic achievement. While the overall weighted mean of the second variable was 2.46 and it was interpreted as always. 
Table 3. Parental financial support and students motivation in leaning

\begin{tabular}{llll}
\hline & Value & Df & Asymp. Sig. (2-sided) \\
\hline Pearson Chi-Square & $4.972 \mathrm{E2}^{\mathrm{a}}$ & 252 & .000 \\
Likelihood Ratio & 242.381 & 252 & .657 \\
Linear-by-Linear Association & 57.152 & 1 & .000 \\
\hline N of Valid Cases & 246 & & \\
\hline
\end{tabular}

a. 285 cells $(100.0 \%)$ have expected count less than 5 . The minimum expected count is .00 .

The table above shows that the p-value (.000) is less than the alpha (0.05). It means that we need to reject the null hypothesis (Ho). Therefore, there is a significant association between the two variables parents' financial support and students' motivation in learning. This result is supported by Chohan's (2010) study which revealed that parental financial support has a significant effect on the students' academic achievement and self-concept. Shahzad (n.d) stated that supportive attitude of the parents is found to be positively associated with students' academic achievement. Ozeen (2017) found out that the importance of motivation plays a significant role in students' academic achievement.

\section{Findings}

This chapter presents the summary of findings, conclusions, recommendations and limitation of the study in relation to the parental financial support and students' motivation in learning.

It was seen that the level of parents' financial support has the result of sometimes based on the weighted mean when it comes to providing and supporting the needs of the students in school such as their allowance and projects.

On one hand, students' level of motivation in learning has the result of always because the students have the positive mindset and belief that they can perform a task according to their capabilities.

Having a high level of parents' financial support affects the students' motivation in learning.

\section{Conclusion}

In this study, it implies that the parents support their children when it comes to school related to financial needs. It is their responsibility to provide what their children needed at school particular in project matter. However, parents support in educational purposes was found sometimes among the students in senior high school. Moreover, students always motivate themselves when it comes in learning because they are afraid that they will be behind and afraid to fail. Thus, students are more motivated to learn if their parents support them in their studies. Parents' financial support and students' motivation has a significant relationship.

\section{Recommendation}

The researcher recommends the parents to support their children financially so that their 
children will be motivated to learn and go to school regularly. Students should be more motivated and eager to learn new things as it will be use in their future work. Teachers should understand the economic capability of their students.

\section{References}

Artino, A., \& Stephens, J. (2009). Academic motivation and self-regulation: Acomparative analysis of undergraduate and graduate students learning online. Journal of Internet and Higher Eucation. https://doi.org/10.1016/j.iheduc.2009.02.001

Chohan, B. I. (2010). Impact of parental support on the academic performance and self-concept of the student. Journal of Research and Reflection in Education, 4(1), 14-26. Retrieved from http://www.ue.edu.pk/jrre

Chohan, B. I., \& Khan, R. M. (2010). Impact of parental support on the academic performance and self-concept of the student. Journal of Research and Reflection in Education, 4(1), 14-26. Retrieved from http://www.ue.edu.pk/jrre.

Coulter, R. (2016). Parental background and housing outcomes in young adulthood. Journal of Social Sciences, 33(2), 201-223. https://doi.org/10.1080102673037.2016.1208160.

Dojillo, J. L., Balandra, J., Lebuna, M. R., \& Lopez, N. E. (2017). The relationship of Moral and Financial Support of Parents to the Academic Performance of the BSHRM students. International Conference on Studies in Arts, Social Sciences And Humanities Journal. https://doi.org/10.7758/URUAE UHO 117434

Dornyei, Z. (2009). Motivation in second and foreign language learning. Journals of Cambridge, 31(3), 117-135. https://doi.org/10.17/s026144480001315X

Ferla, J., Valeke, M., \& Schuyten, G. (2010). Judgements of self-perceived academic competence and their differential impact on students achievement motivation, learning approach, and academic performance. European $J$ Psycho Educ. https://doi.org/10.1000/s10212-010-0030-9

Garn, A., Matthews, M., \& Jennifer, J. (2010). Parental influences on the academic motivation of gifted students: A self-determination theory perspective. Journal of Gifted Child Quarterly, 54(4), 263-272. https://doi.org/10.1177/001698621037

Ghazi, S. R., Ali, R., Shahzad, S., Khan, M. S., \& Hukamdad. (2010). Parental involvement in children academic motivation. Asian Social Science Journal, 6(4), 93-99. Retrieved from https://www.researchgate.net/publication/42368665_Parental_Involvement_in_Children_Aca demic_Motivation

Huang, J., Guo, B., Kim, Y., \& Shewaden, M. (2009). Parental income, assets, and borrowing constraints and children's post secondary education. Journal of Parental Income, Assets, Borrowing Contraints. https//www.sciencenet.com/science/article/pii/S0190740909003557

Kim, D. H., \& Schneider, B. (2017). Social capital in action alignment of parental support in adolescents transition to post secondary education. OXFORD Journals, 84(2), 1181-1206. 
Retrieved from http://www.jstor.org/stable/3598495

Kim, K., Fingerman,K., Birditt, K., \& Zarit, S. (2015). Capturing between-and within-family pifferences in Parental support to adult children: A typology approach. Journals of Gerontology: Psychological $\quad$ Sciences, $\quad 71(6), \quad$ 1034-1045. https://doi.org/10.9/093/gerohb/gbv029

Machebe, C. H., Ezegbe, B., \& Onuoha, J. (2017). The impact of parental level of income on students academic performance in high school in Japan. Universal Journal of Education Research, 5(9), 1614-1620. https://doi.org/10.13189/6jer.2017.050919

Mahuro, G. M., \& Hungi, N. (2016). Parental participation in improves students academic achievement: A case of iganga and mayuge districts in uganda. Journal of Cognet Education. https://doi.org/10.1080/2331186X.2016.1264170

Masabo, L., Muchopa, E., \& Kuoth, W. (2017). Parental involvement in school activities inkibondo district, tahzania: Challenges and emedias. International Reflections in Education, 4(1), 14-26. Retrieved from Http//:www.ue.edu.pk/jrre

Moore, L., Grabsch, D., \& Rotter, C. (2010). Using achievement motivation theory to explain student participation in a residential leadership learning community. Journals of Leadership Education, 9(2), 22-34. Retrieved from https//www.researchgate.net/publication/274298897_Using_Achievement_Motivation_Theor y_to_Explain_Student_Participation_in_a_Residential_Leadership_Learning_Community

Norvilitis, J. (2010). The role of parents in college students financial behaviors and attitudes. Journals of Economic Psychology. https://doi.org/10.1016/j.joep.2009.10.003

Olivos, P. (2016). The relationship between learning types and motivation to transfer of learning in vocational training programme. Suma Psicologica Journal. https://doi.org/10.1016/j.sumpsi.2016.02.001

Ozen, S. O. (2017). The effect of motivation on student achievement. Journal of Springer International Publishing. https://doi.org/10.1007/978-3-319-56083-0-3

Radovan, M. (2011). The relationship between distance students motivation, their use of learning strategies, and academic success. The Turkish online Journal of Education Technology, 10(1), 216-222. Retrieved from https//www.researchgate.net/publication/279899305_Therelation_between_distance_students '_motivation_their_use_of_learning_strategies_and_academic_success

Riswanto, A. (2017). Learning motivation and students achievement: Descreption analysis and relationship both. The International Journal of Counseling and Education, 2(1), 42-47. https://doi.org/10.23916/002017026010

Saeed, S., Zyngier, D., \& David, Z. (2012). How motivation influences student engagement: A qualitative case study. Journal of Education and Learning, 1(2), 252-267. https://doi.org/10.5539/jel.vln2p52 


\section{Al Macrothink}

Issues in Social Science

ISSN 2329-521X 2020, Vol. 8, No. 1

Saeid, N., \& Eslaminejad, T. (2017). Relationship between students self-directed-learning readiness and academic self-efficacy and achievement motivation in students. Journal of International Education Studies, 10(1), 225-231. https://doi.org/10.5539/ies.v101p225

Saleh, S. (2014). Students motivation towards physics learning. European Journal of Science and Mathematics Education, 2(4), 223-234. Retrieved from https//www.researchgate.net/publication/281277079_Malaysian_students'_motivation_towar ds_Physics_learning

Seifert, T. (2004). Understanding student motivation. Journal of Educational Research, 46(2), 138-149. https://doi.org/10.1080/0013188042000222421

Shahzad, M., Abdullah, F., Fatima, S., Riaz, F., \& Mehmood, S. (2005). Impacts of parental support on academic performance among secondary school student in islamabad. Journal of Social Sciences, 1(7), 228-231. Retrieved from http//www.theexplorepak.org

Vibulphol, J. (2016) Students motivation and learning and teachers motivational strategies in english classroom in thailand. Journal of English Language Teaching, 9(4), 64-73. https://doi.org/10.5339/elt.v9n4p64

Vos, N., Meijden, H., \& Denessen, E. (2010). Effects of constructing versus playing an educational game on student motivation and deep learning strategy use. Computers and Education Journal. https://doi.org/10.1016/j.comp.edu.240.08.013

West, A., Lewis, J., Roberts, J., \& Noden, P. (2016) Young adult graduates living in the parental home: Expectations, negotiations and Parental financial support. Journal of Family Issues. https://doi.org/10.1177/01925/3X16643745

Wightman, P., Patrick, M., Schoeni, K., \& Schulenberg, J. (2013). Historical Trends in Parental Financial Support of Young Adults. Population Studies Center Journal. http//www.psc.isr.umich.edu

\section{Glossary}

Parental Financial Support refers to the provision of monetary resources including money or capital provided by parents.

Student's motivation in Learning refers to the students drive in doing things that can help them without forced by the teachers.

\section{Appendix}

Appendix 1.Survey Questionnaire for Parental Financial Support

\section{TOOL: CHECKLIST}

Instruction: Please respond to the following statements by writing the number that corresponds to your answer. You write 3 for Always, 2 for Sometimes and 1 for never. This 


\section{Ml Macrothink}

tool will assess your financial support and motivation in Learning. Please answer with honesty and as truthfully as you can, the data will be held privately/secretly and will be used only for academic research purposes.

Name:

Age:

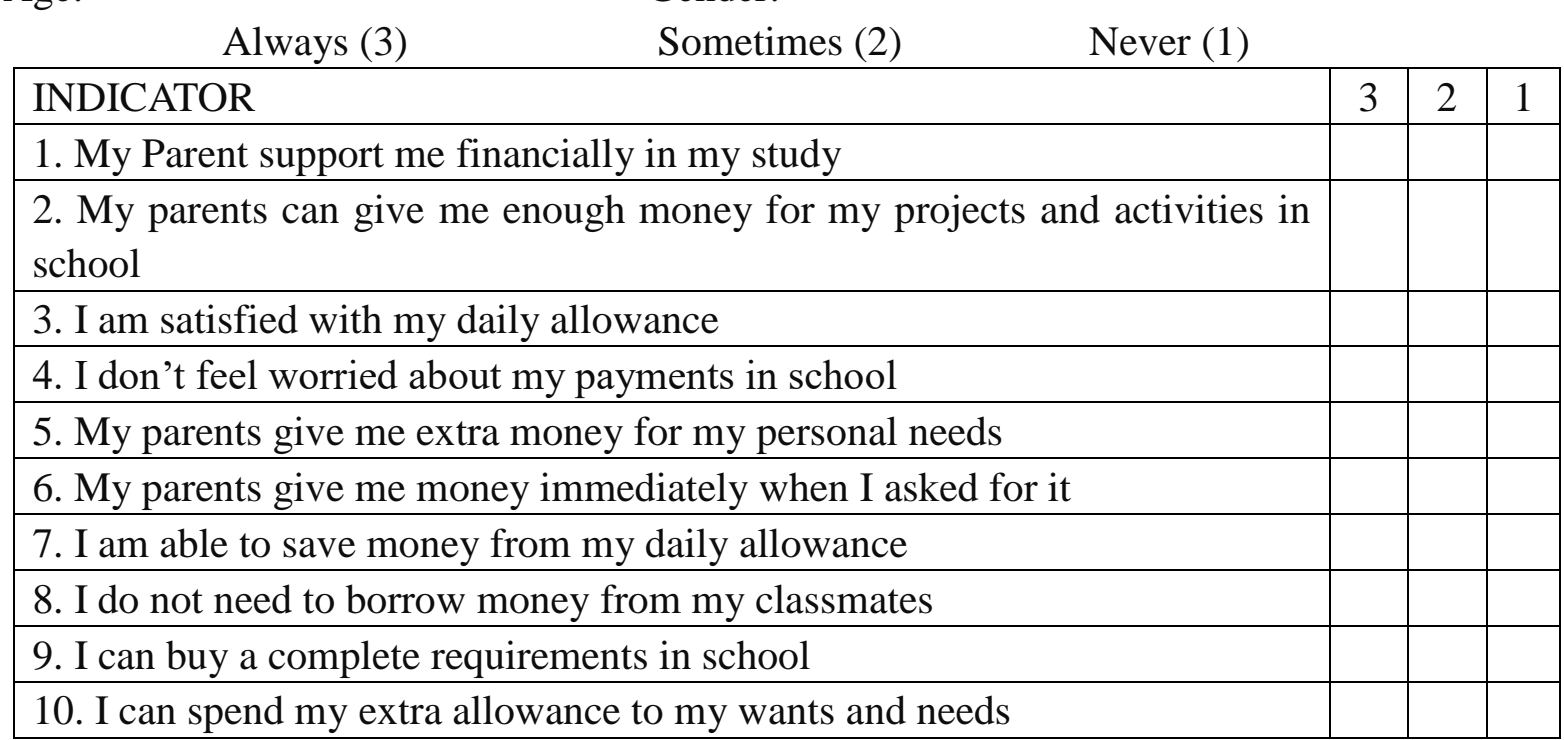

Part 2: Motivation in Learning

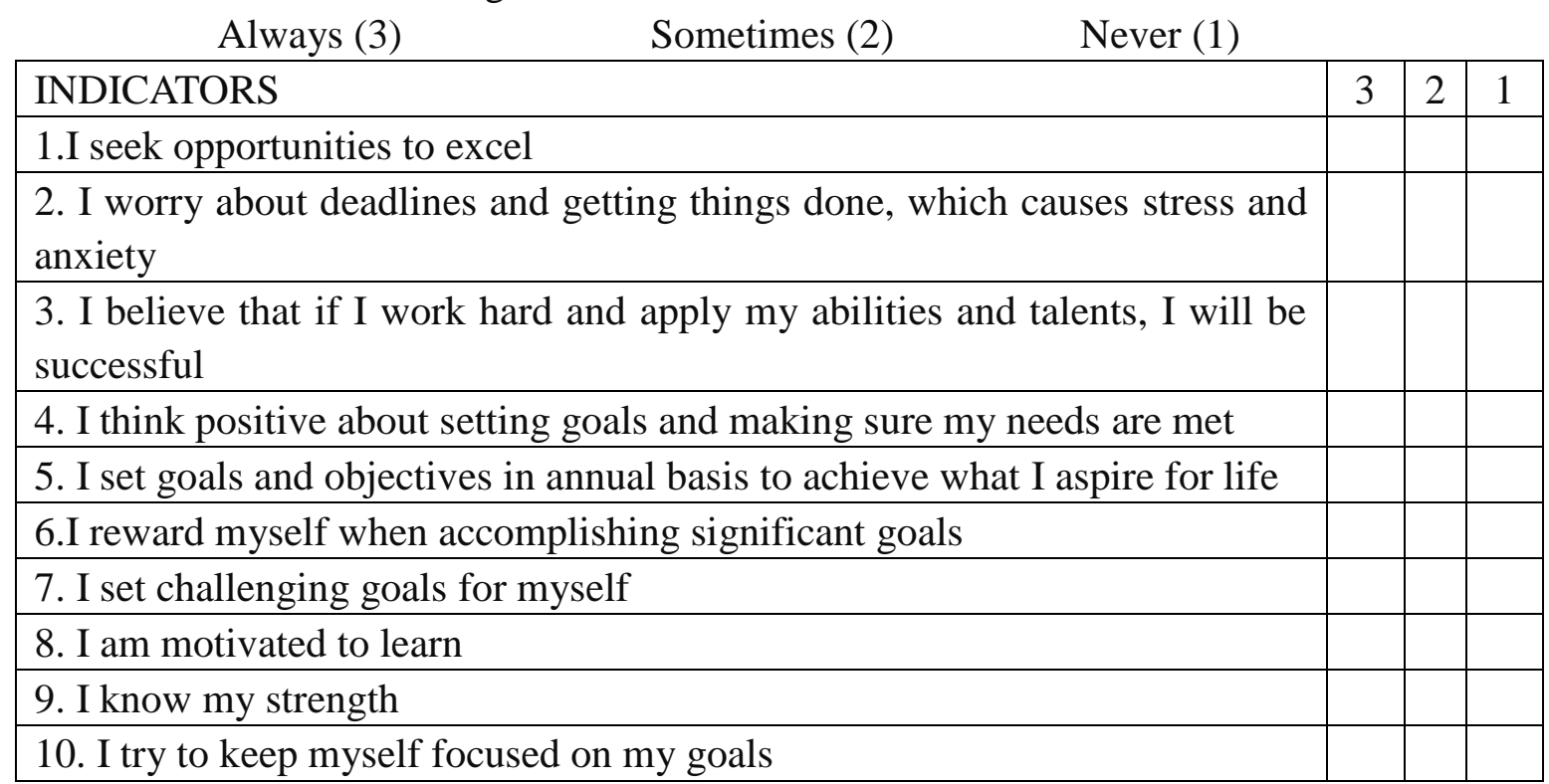

\section{Copyright Disclaimer}

Copyright for this article is retained by the author(s), with first publication rights granted to the journal.

This is an open-access article distributed under the terms and conditions of the Creative Commons Attribution license (http://creativecommons.org/licenses/by/3.0/). 